\title{
Innovative Irrigation Techniques in Nursery Production to Reduce Water Usage
}

\author{
John N. Kabashima \\ South Coast Research and Extension Center, 7601 Irvine Boulevard, Irvine, CA 92718
}

\begin{abstract}
Growers throughout California are being forced to evaluate the potential liability of runoff from their operations because of Proposition 65 (California Safe Drinking Water and Toxic Enforcement Act of 1986), the Ground Water Protection Program (California Pesticide Contamination Prevention Act of 1985, Assembly Bill 2021), and arbitrary zero tolerance limits set by local agencies and advocated by environmental groups (Drushal, 1990). The primary water issues for California's nursery industry are 1) water availability and cost during the current and future droughts, 2) water runoff, and 3) nitrate and pesticide pollution of groundwater and bodies of water. These problems have caused nurseries to change their management practices and adhere to public policy, or discontinue business in their geographic areas. Due to the water quantity used and nitrates in runoff water from their operations that are polluting the Newport Back Bay (Newport Beach, Calif.), three nurseries in Irvine, Calif., were among the first in California to implement techniques to reduce water usage and runoff. Each of the operations has taken a slightly different approach to the problem as discussed below.
\end{abstract}

\section{Nursery 1}

This 81-ha nursery built a reservoir and recycling system to save water before government agencies demanded reduced runoff. Based on water prices of $\$ 162 / 1000 \mathrm{~m}^{3}$, they believed that, by recapturing $60 \%$ of irrigation runoff, the system would pay for itself within 2 years. A simple recycling system was designed to channel irrigation runoff water to sedimentation pits, where coarse materials are filtered through nets and screens and settled out. This water then is run through sand filters and pumped to a reservoir.

By recapturing part of their irrigation runoff, shortening irrigation run times, and using drip irrigation where feasible, this nursery was able to reduce its total annual water usage (AWU) by $70 \%$, from 2.46 $\times 10^{9}$ liters in 1984 to $0.8 \times 10^{9}$ liters in 1989 . This nursery also reduced water runoff by $88 \%$, from $1.28 \times 10^{9}$ liters in 1984 to $0.095 \times 10^{9}$ liters in 1989 (Dominge, 1990).

\section{Nursery 2}

This nursery had to comply with strict governmental regulations for reducing water runoff when they had only $\approx 9$ years left on their land lease. Faced with higher material costs, more stringent requirements from the water quality board, and a 9-year lease, they designed a system for their 160-ha nursery that would pay for itself within 8 years.

To attain an 8-year payback, the nursery set a goal of capturing $75 \%$ to $80 \%$ of their irrigation runoff. In 1984, their water usage was 2.12 $\times 10^{9}$ liters; by 1989 , they had reduced it by $46 \%$ to $1.58 \times 10^{\circ}$ liters. 
Water runoff in 1984 was $9.54 \times 10^{8}$ liters and was reduced by $25 \%$ to $7.1 \times 10^{8}$ liters in 1989 (Guttman, 1990).

Nursery 2 implemented an improved recycling system by using concrete-lined channels in major flow areas to reduce irrigation runoff seepage into the soil. To reduce runoff from the nursery further, plants grown in the same container size were moved to the same section of the nursery. Plants grown in small containers ( $<4$ liters) are watered by overhead irrigation, with all runoff recaptured and held in a $1.58 \times 10^{6}$ liter reservoir. Drip irrigation was installed for plants in larger $(>7$ liters) containers, and runoff was practically eliminated from this section.

The Can Test Method of auditing all overhead sprinklers and drip systems is part of their irrigation improvement program (Snyder, 1991). Automated controllers were installed in various sections of the drip system to improve control over irrigation run times.

Supervisors train irrigators to irrigate for shorter periods and to check the soil moisture level manually before irrigating to determine if plants need water. Worn nozzle orifices were a major cause of poor irrigation distribution uniformity. Section managers check sprinkler head orifices periodically by sliding in drill bits of known sizes and replacing any worn nozzles immediately.

\section{Nursery 3}

The owners felt that their current practice of watering plants for 30 min, a common practice when water was inexpensive and runoff was not a factor, resulted in too much runoff. They theorized that, if they applied a small amount of water five or six times daily at hourly intervals, instead of one heavy daily watering, the water would slowly saturate the soil with very little water being leached through container drainage holes. This technique is called "pulse irrigation." But how to turn 1 million drip irrigation emitters and numerous sprinklers on or off hourly in a 40-ha container plant operation?

They put all irrigation controllers on a computer-controlled system (Whitesides, 1989). The computerized watering system setpoints are selected each day to account for that day's temperature, humidity, and wind speed, the previous day's weather; and the forecast for the next day. On cool, cloudy, windless days, their computer program reduces watering, while on hot sunny days, or when a hot dry wind is blowing, irrigation is increased. They recognized that greater accuracy could be achieved with the California Irrigation Management Information Systems Reference Evapotranspiration $\left(\mathrm{ET}_{0}\right)$ figures and are investigating using this database, which is available through the California Dept. of Water Resources computer. In addition, this nursery is also experimenting with a capillary mat subirrigation system.

As a result of using drip irrigation and computerizing their irrigation system, this nursery used $5.3 \times 10^{7}$ liters of water in 1986 and $4.1 \times 10^{7}$ liters in 1989 , a reduction of $30 \%$. Water runoff- $2.27 \times 10^{7}$ liters in 1986-was reduced $77 \%$ in 3 years to $0.64 \times 10^{7}$ liters (Groot, 1990).

\section{Other considerations}

Varying environmental conditions in other parts of California make using other methods to reduce water usage and runoff possible. One nursery in northern California, because of periodic water shortages and water prices as high as $\$ 567 / 1000 \mathrm{~m}^{3}$, has developed five potential water sources: 1) wells, 2) water district water, 3) runoff from local hills (watershed), 4) irrigation water runoff, and 5) runoff water from rainfall and fog. They also maximize runoff capture by using cement and asphalt to reduce irrigation runoff percolation into the ground.

There is strong and persistent pressure from government agencies, politicians, and environmental groups for the Regional Water Quality Control Board (RWQCB) to deny discharge permits to these nurseries unless they can achieve zero nitrate runoff. The RWQCB, however, recognizes that such an action would force the nurseries to close and has developed guidelines and goals that minimize nitrate concentrations and runoff, while allowing the nurseries to remain in business.

\section{Discussion}

One of the major differences between Nurseries 1 and 2, and
Nursery 3 is AWU. In 1989, Nursery 1's AWU was $9.86 \times 10^{6}$ liters $\cdot \mathrm{ha}^{-1}$, and Nursery 2 used $9.88 \times 10^{6}$ liters $^{-h^{-1}}{ }^{-1}$ annually. This AWU per hectare is 9.6 times that of Nursery $3\left(1.03 \times 10^{6}\right.$ liters.ha $\left.{ }^{-1}\right)$. Nurseries 1 and 2 are both large operations that grow a variety of outdoor container ornamental plants. These plants are irrigated by overhead sprinklers if they are in small containers ( $<4$ liters) or by drip irrigation if they are in large ( $>7$ liters) containers. Nursery 3 primarily grows flowering potted plants in small containers ( $<4$ liters), which are a higher valued crop and can be watered with drip irrigation. This difference indicates that water savings, based on orders of magnitude, can be accomplished using drip rather than overhead irrigation. Nursery 3 uses a computer to control all irrigation solenoids in the nursery and highly qualified and skilled labor (college graduates) to operate the system. Nurseries 1 and 2 use highly qualified supervisors to monitor and train unskilled field laborers, who manually turn irrigation valves on or off.

Short- and long-term research in water usage and runoff reduction is needed. Short-term research would help growers who must comply with governmental or economic pressures, such as extremely high water prices, in a short period. Lieth and Burger's research (1989, 1990) using tensiometers and computers to maintain constant soil moisture tension and Burger et al.'s (1987) research using crop coefficients to group plants into heavy, moderate, and light water users are procedures that growers can adopt fairly quickly to adjust their irrigation techniques. Such technology transfer, however, will entail a concentrated effort to teach the less sophisticated growers how to adopt these new technologies. Educational programs also are needed to teach growers how to evaluate and improve their irrigation systems, determine plant water requirements and apply them toward minimizing or eliminating runoff, and select the most cost-effective system for their operation.

Investigating economic factors that may arise when a grower changes his/her irrigation practices is also important. During the 1991 recession, growers, especially those operating on leased land, with limited cash flow or credit found it difficult to invest in hardware that required a computer control system, recycling system, or new sprinkler system. A new or unproven system must first be tested on a small scale to familiarize users with its operation.

Potential long-term research should focus on improving current systems and developing new watering techniques that meet a plant's requirements without runoff or negative side effects, such as salt buildup or increased disease incidence. The research ideally would be conducted by a multidisciplinary team of scientists.

\section{Conclusion}

Challenges to the future of California's nursery industry are water availability and quality, affordable water prices, and management practices that conform to public policy mandating decreased water usage, runoff, and nitrate and pesticide pollution of groundwater and surface water. Nurseries have met these challenges by reducing water usage and runoff through pulse, drip, and computer-controlled irrigation; recycling water; auditing irrigation systems to increase system uniformity; and using the California Irrigation Management Information Systems and ET, to determine crop water requirements. Growers and researchers must continue to improve current irrigation systems and develop new technologies to water crops in an economically feasible manner without compromising production or quality.

\section{Literature Cited}

Burger, D.W., J.S. Hartin, D.R. Hodel, T.A. Lukaszewskj, S.A. Tjosvold, and S.A. Wagner. 1987. Water use in California's ornamental nurseries. Calif. Agr. 41(9-10):7-8.

Dominge, R. 1990. Water and nitrate use and runoff report for Bordiers Nursery. Hearing California Regional Water Quality Control Board, Santa Ana, 12 July 1990.

Drushal, N.L. 1990. Greenhouses, ground water and government: You're not alone. GrowerTalks 54(5):60-66.

Groot, P. 1990. Water and nitrate use and runoff report for El Modeno Gardens. Hearing California Regional Water Quality Control Board, Santa Ana, 12 July 1990. 
Guttman, G. 1990. Water and nitrate use and runoff report for Hines Nursery. Hearing California Regional Water Quality Control Board, Santa Ana, 12 July 1990.

Lieth, J.H. 1990. Irrigation technology: Reducing runoff in greenhouse and nursery production. Proc. Soc. Amer. Florists 6th Conf. Insect and Disease Management on Ornamentals, Feb. 1990, San Jose, Calif. P133-140.

Lieth, J.H. and D.W. Burger. 1989. Growth of chrysanthemum using an irrigation system controlled by soil moisture tension. J Amer. Soc. Hort. Sci. 114:387-392.

Snyder, R.L., L.J. Schwankl, D.A. Shaw, J.K. Kabashima, and MA. Hativandi. 1991. Turfgrass irrigation scheduling. Coop. Ext., Univ. of California, Div. of Agriculture and Natural Resources Lflt. 21492.

Whitesides, R. 1989. El Modeno Gardens: Innovative solutions to California's irrigation runoff restrictions. GrowerTalks 59(2):28-36. 